\title{
Editorial Foreword 72.3 (August 2013)
}

\section{Our Cover}

Our cover photograph was provided to us by Yidi Wu, currently a graduate student in the history department at the University of California, Irvine. She and her cousin Liu Yiqing, a photographer working for China Water \& Power Press in Beijing, visited North Korea as tourists in the summer of 2011, when Kim Jong Il was still in power. Liu took this snapshot of a tram in Pyongyang. On the side is written "Serving the People!" A peek into the windows shows passengers lost in thought, chatting with friends, reading, and, in one case, carrying a musical instrument. Photo used by permission.

\section{Asia Beyond the Headlines, and Trends}

This issue opens with both an "Asia Beyond the Headlines" and a "Trends" piece that, though very different, have two basic things in common. Each is concerned with contemporary China and, in part at least, economic issues. The first, KAREN EgGLESTON ET AL.'s "Will Demographic Change Slow China’s Rise?," showcases the findings of a team of five social scientists interested in recent Chinese developments and their implications for the country's future. Their conclusion, after examining census data and materials associated with labor and productivity, is that the years ahead will be very challenging ones for a government that has prided itself on the ability to deliver high growth rates while maintaining social stability. Gender imbalances within China and the aging of the Chinese population are, they claim, among the key factors with which the authorities will increasingly have to contend.

The second essay in this pair, political scientist Gregory T. Chin’s “Understanding Currency Policy and Central Banking in China," takes us from demography and production to the realm of finance. The author begins by noting how "daunting" it is, due to the "opaque Chinese policy process," to gain the kind of clear overview of China's banking realm that is possible in some other neighboring countries, such as Japan. Nonetheless, he is able to develop a clearer picture of many issues, including currency exchange policies and the roles of different sorts of financial institutions, via a combined reading of several recent works.

\section{Research Articles}

The second section of the issue begins with a pair of very different articles that, in divergent ways, revisit themes of gender, femininity, and masculinity that figured in 
last November's "Gender Across Asia” special issue of this journal. In the first, "Enlightenment Geisha: The Sex Trade, Education, and Feminine Ideals in Early Meiji Japan," historian AMY STANLEY provides readers with a carefully crafted and multifaceted look at a group of women who, as she notes, often figure centrally in "movies, novels, paintings, and prints" produced on "both sides of the Pacific," yet "rarely appear as protagonists in historical scholarship on modern Japan." The issues Stanley examines include the complexity of the category under analysis, the challenge that the existence of a distinctive kind of sex trade posed for Japanese intellectuals striving to present Japan as a country in step with "Anglo-American norms of sexual morality," and how Meiji-era feminists viewed geisha as individuals and symbols.

In the second of these two articles, Louise Edwards, Professor of Modern China Studies at the University of Hong Kong, takes readers forward in time to World War II and across to sea to the Chinese mainland. Her article, "Drawing Sexual Violence in Wartime China: Anti-Japanese Propaganda Cartoons," shows that, as in other settings involving invading armies, "depictions of sexual violence inflicted on Chinese women" figured centrally in efforts to "arouse the spirit of resistance." The author suggests that depictions of horrors committed against Chinese women by Japanese soldiers were expected to have a galvanizing effect, quite different from the dispiriting impact of portrayals of badly injured Chinese men, for representations of the latter could "sap morale and hamper the war effort."

The third article in the main section also deals with the war years of the middle of the last century, but takes us back to Japan. The focus in historian ERIC Han's essay is Yokohama's Chinese community. How, the author asks, did this group struggle to "maintain both its Chinese identity and its position in local society" once China and Japan were at war? Key themes addressed in "A True Sino-Japanese Amity? Collaborationism and the Yokohama Chinese (1937-1945)" include the "nature of Sino-Japanese friendship, hidden resistance, and local integration." This micro-history of a specific Japanese port sheds new light on the kinds of issues of collaboration that are most often explored in colonial or conquest settings, while also adding a novel case study to the literature on the Chinese diaspora.

Next come a pair of articles dealing with religion and India, though in both cases in unexpected ways. The first of the two, historian Nile Green's "Forgotten Futures: Indian Muslims in the Trans-Islamic Turn to Japan," which looks deeply into Urdu writings on Japan, illuminates the role that Japanese political developments of the early 1900s played in inspiring Indian Muslims to envision the possibility that new kinds of states could be founded in South Asia. Indian actors, like their counterparts in other parts of Asia, were determined to try to discover the "secret" of the "Japanese ascent"-to borrow words from a poem Green quotes to open his article-and put this powerful recipe to new purposes, such as, in this case, transforming extant princely states into novel Muslim-ruled entities.

Green's article is followed by ChaD M. Bauman's "Hindu-Christian Conflict in India: Globalization, Conversion, and the Coterminal Castes and Tribes," which focuses on a much more recent set of actors but also looks at a largely unexplored subject. Whereas "Hindu-Muslim violence in India has received a great deal of scholarly attention," according to Bauman, a religious studies scholar, "Hindu-Christian violence has not." After providing readers with a "short history of Hindu-Christian relations," 
Bauman examines the "uptick in anti-Christian violence" of recent decades, arguing that one cause of it has been the way that the religion "has come to stand, symbolically, as a proxy" for globalization.

Before going on to provide our usual array of reviews of works on different parts of Asia, the issue's main section closes with an article by political analyst CHANGYONG CHOI, “Everyday Politics' in North Korea." This piece bears much in common with works we have begun to run under that rubric. Like them, it takes an issue in the news (North Korean politics) and explores a dimension of the story that is often left out or misunderstood (in this case the quotidian as opposed to state spectacle and state repressive sides of political life). It is longer and more formally written than our typical "Asia Beyond the Headlines" essays, but it could be very usefully read (and perhaps taught) alongside a contribution to that genre, "The Politics of Everyday Life in Twenty-First Century Myanmar" (in 70.3), which we ran two years ago and which Choi cites.

\section{Forthcoming Articles in JAS 72.4 (November 2013)}

Asia Beyond the Headlines

The Khmer Rouge Tribunal: A Politically Compromised Search for Justice

Kheang Un

Trauma and Its Aftermath: Local Configurations of Reconciliation in Cambodia and the Khmer Rouge Tribunal

Eve Monique Zucker

The CAG and Corruption in India

Ronojoy SEN

Presidential Address

Disasters: Natural and Unnatural Reflections on Japan after 2011

TheOdore Bestor

\section{JAS at AAS Roundtable}

Global Capitalisms in Asia: Beyond State and Market in China John Osburg

From Wall Street to Halal Street: Malaysia and the Globalization of Islamic Finance Daromir Rudnyckyj

Discussion

Donald K. Emmerson 
Research Articles

The Han Minzu: Fragmented Identities and Ethnicity AgnieszKa Joniak-LÜThi

Progressives and Labor: A Forgotten Alliance in 1960s South Korea HWASOOK NAM 